\title{
Growth hormone protects against radiotherapy-induced cell death
}

Olga Madrid, Silvia Varea, Isabel Sánchez-Pérez, Lourdes Gómez-García ${ }^{1}$, Enrique De Miguel ${ }^{1}$, Ignacio A Gómez de Segura ${ }^{1}$ and Rosario Perona

Instituto de Investigaciones Biomédicas del CSIC/UAM, Arturo Duperier 4, Madrid 28029, and ${ }^{1}$ Unidad de Investigación, Hospital Universitario La Paz, Castellana 261, Madrid 28046, Spain

(Correspondence should be addressed to E De Miguel; Email: emiguel@hulp.insalud.es)

\begin{abstract}
Background: In vivo treatment with growth hormone reduces radiation-associated mortality. The molecular mechanisms underlying this effect are unknown. It has been described that increased sensitivity to ionising radiation can be due to defects in machinery involved in detection and/or repair of DNA double-strand breaks.

Objective: To study the mechanisms involved in growth hormone action on the increased survival in irradiated cells.

Materials and methods: CHO-4 cells stably expressing the growth hormone receptor were used. A cell viability assay was carried out to analyse the increase in survival induced by growth hormone in irradiated cells. To investigate whether the DNA repair mechanism could be implicated in this effect we performed DNA reactivation assays using pHIV-LUC and pCMV- $\beta$ gal plasmids as control. Identical studies were also conducted using the radiomimetic drug, bleomycin.

Results: Growth hormone protects CHO-4 cells from bleomycin- and radiation-induced cell death. In pHIV-LUC transfected cells, a time-dependent decrease in luciferase activity was observed after irradiation in the absence of growth hormone. However, cells pretreated with this hormone maintained reporter activity. When cells were transfected with irradiated pHIV-LUC plasmid, only the hormone-treated cells recovered the transcriptional activity.

Conclusions: Growth hormone exerts a radioprotective effect in CHO-4 cells stably transfected with the complementary DNA for the rat growth hormone receptor. The radioprotection is triggered directly by the hormone and it is also observed with bleomycin. The increased survival in response to radiation and bleomycin treatment induced by growth hormone correlates with an enhanced ability of the cells to repair damaged DNA.
\end{abstract}

European Journal of Endocrinology 147 535-541

\section{Introduction}

The cell nucleus is considered the primary target for the lethal effects of ionising radiation and the heterologous DNA double-strand breaks are the most common type of radiation lesions that lead to mammalian cell death (1). However, the outcome of this damage is not necessarily cell death since mammalian cells can repair radiation-induced DNA breaks proficiently (2). Radiation-induced damage in DNA and other cellular components triggers cascades of regulatory events in eukaryotic cells. These events constitute a complex network of pathways towards cell cycle checkpoints, DNA repair and damage tolerance mechanisms, recombination and programmed cell death (apoptosis). Several pieces of evidence suggest that certain growth factors and cytokines can modify cellular radiosensitivity. Thus, basic fibroblast growth factor (bFGF) protects bovine aortic and murine intestinal endothelial cells against radiation-induced programmed cell death $(3,4)$; insulin-like growth factor (IGF)-I (5), keratinocyte growth factor (6), vascular endothelial growth factor (VEGF) (7) and acid and basic FGFs (8) exert protective effects on intestine from radiation injury; interleukin (IL)-1, IL-11, IL-12 and tumour necrosis factor (TNF)- $\alpha$ are radioprotective in the murine bone marrow $(9,10,11)$. Given before radiation, IL-1, IL-11 and transforming growth factor (TGF- $\beta$ )-increase the number of surviving intestinal crypts after radiation (12-14).

Growth hormone $(\mathrm{GH})$ is an anabolic hormone with pleiotropic effects on growth, differentiation and metabolism of cells (15), although it does not stimulate in vitro human tumour growth (15). In general, GH 
initiates its biological actions by interaction with a specific membrane-bound receptor (15). The GH receptor is phosphorylated upon ligand stimulation by physical association with the non-receptor tyrosine kinase JAK2. JAK kinases are linked to transcriptional regulation and their activation results in the phosphorylation, dimerisation, and nuclear translocation of latent cytoplasmic STAT transcription factors. These activated STAT factors bind to their appropriate DNA-responsive elements and activate gene transcription (16).

GH has been clinically used in GH-deficient children (17) and adults (18), in patients recovering from surgery (19) and in patients with intestinal diseases like Crohn's syndrome (20) and inflammatory bowel disease (21). GH stimulates muscle protein synthesis, improves the nitrogen balance and promotes wound healing in a variety of catabolic states $(22,23)$. In addition, GH has been shown to reduce radiationassociated mortality (24). In this context, it has been reported that, within the bowel of radiated rats, $\mathrm{GH}$ favours the absorptive process by increasing mucosal proliferation and villous size (24). This protection exhibits an increase in intestinal crypt proliferation and a reduction in apoptosis. The mechanism by which GH reduces the effect of radiation is unknown. Here we used an in vitro cell system to further investigate the influence of $\mathrm{GH}$ on radiation responses. The results presented here indicate that $\mathrm{GH}$ has a protective action against radiation and this effect seems to be mediated by its ability to increase the repair of radiation damaged DNA.

\section{Materials and methods}

\section{Cell lines and plasmids}

Chinese hamster ovary (CHO)-4 and human embryonic kidney (HEK) 293T cells were cultured in Ham's F-12 medium or Dulbecco's modified Eagle's medium respectively containing $4.5 \mathrm{~g} / \mathrm{l}$ glucose and supplemented with $10 \%$ fetal calf serum (FCS) and $1 \mathrm{mM}$ L-glutamine. pHIV-LUC (25) contains sequences $-453 /+80$ from the HIV enhancer linked to the firefly luciferase gene. PCMV- $\beta$ gal plasmid contains the prokaryotic $\beta$-galactosidase gene inserted between the cytomegalovirus promoter (CMV) and the SV40 splice and polyadenylation signals. SPIGLE1 plasmid containing the GAS sequence from the SPI 2.1 promoter was kindly provided by Dr Ugo Moens (26).

\section{DNA reactivation assays}

CHO-4 cells were plated $24 \mathrm{~h}$ before transfection at a density of $3 \times 10^{5}$ cells $/ 60 \mathrm{~mm}$ plate. Cells were transfected with the plasmid pHIV-LUC by the calcium phosphate method as described (25). Sixteen hours after transfection cells were fed with low serum medium $(0.5 \%)$ and treated with different concentrations of recombinant human GH (hGH, Serono, Madrid, Spain) for a further $4 \mathrm{~h}$. Then, cells were irradiated using a telecobaltotherapy unit (60CO27 Model Theratron-80, MDS Nordion, Kanata, Ontario, Canada). Cell extracts were obtained as described before (25) at different times after irradiation and assayed for luciferase activity. Alternatively pHIV-LUC plasmid was irradiated with different doses and transfected together with pCMV- $\beta$ gal plasmid as a control, by the calcium phosphate method. Sixteen hours after medium was removed, cells were fed with low serum medium $(0.5 \%)$ and supplemented when indicated with different doses of GH. Cells extracts were prepared $48 \mathrm{~h}$ after transfection and assayed for $\beta$-galactosidase and luciferase activity. Fold activation was obtained by normalising luciferase activity to $\beta$-galactosidase expression.

\section{Gene expression analysis}

Cells were transfected with the indicated plasmids and harvested at different times after treatment. Protein extracts were prepared by three consecutive cycles of freezing and thawing. The total amount of protein was determined with a commercial kit based on the Bradford method (BioRad, Hemel Hempstead, UK). Ten to twenty micrograms of protein was assayed for cloramphenicol acetyl transferase (CAT) activity using a xylene-based method. Briefly, total volume for each cellular extract was adjusted to $85 \mu \mathrm{l}$ with $0.25 \mathrm{M}$ Tris- $\mathrm{HCl}(\mathrm{pH}$ 7.5) and then a mixture containing $32 \mu \mathrm{l} 0.25 \mathrm{M}$ Tris-HCl, $5 \mu \mathrm{l}$ butyril $\mathrm{CoA}(5 \mathrm{mg} / \mathrm{ml})$ and $3 \mu \mathrm{l} \quad\left[{ }^{14} \mathrm{C}\right]$ cloramphenicol $(0.1 \mathrm{mCi} / \mathrm{ml})$ was added. The reaction mixture was incubated for $4 \mathrm{~h}$ at $37^{\circ} \mathrm{C}$ and the reaction was stopped by addition of a mixture of 2:1 2,6,10,14-tetramethylpentadecane (Pristane, Sigma): xylene isomer (Sigma, St Louis, Missouri, USA). The mixture was shaken vigorously for $30 \mathrm{~s}$ and spun at 14000 r.p.m. for $15 \mathrm{~min}$. Two hundred microlitres of the upper phase were taken and added to $4 \mathrm{ml}$ Optiphase Highsafe 2 liquid scintillation cocktail (Perkin Elmer Life Sciences, Boston, USA). Total counts (counts per minute, c.p.m.) were detected using a 1214 beta liquid scintillation counter and normalised against micrograms of protein. Luciferase activity was determined with a commercial kit (Promega, Madison, WI, USA). $\beta$-galactosidase activity was assayed as described elsewhere (25) by using $o-p$ nitrophenil phosphate as a substrate.

\section{Cell viability assay}

Cell viability was studied using a Crystal Violet-based staining method. Briefly, cells were plated in $60 \mathrm{~mm}$ plates at a density of $1 \times 10^{4}$ cells/plate. Sixteen hours after seeding cells were serum depleted and treated with different doses of $\mathrm{GH}$ during a further $4 \mathrm{~h}$ and subjected to different doses of radiation. Cells 
were allowed to grow for 10 days, fixed with glutaraldehyde and stained with Crystal Violet as previously described (27). Alternatively cells were seeded at a density of $20 \times 10^{4}$ cells in 24 -well dishes and stained after $72 \mathrm{~h}$ of treatment.

\section{Results}

\section{Treatment of cells with GH increases cell survival after irradiation}

Several in vitro models have been developed to study regulation via the $\mathrm{GH}$ receptor $(28,29)$. For this study we chose CHO-4 cells, which express rat GH receptor cDNA, and as a control cell line, HEK293T cells that are not responsive to GH. In order to establish the response conditions of the two cell lines we carried out transfection experiments using a reporter plasmid, SPIGLE1, containing the GAS sequence from the SPI 2.1 promoter and a STAT5 binding site (30). Both HEK293T and CHO-4 cells were transfected with either the reporter plasmid or the empty vector. As expected, even at high doses of GH, HEK293T cells did not present variations in promoter-driven transcription (Fig. 1). On the contrary, in CHO-4 cells, there was a dose-dependent activation of the promoter in response to $\mathrm{GH}$ at doses that have not been described to be antagonistic (31). These results confirmed that the two systems were suitable for our purposes. In order to investigate the potential role of $\mathrm{GH}$ in radiological protection, HEK293T and CHO-4 cells were seeded at low density in $60 \mathrm{~mm}$ dishes, deprived of serum for $16 \mathrm{~h}$ and treated with different doses of $\mathrm{GH}$ for $4 \mathrm{~h}$. Cells were then subjected to irradiation and allowed to grow for 10 days. As shown in Fig. 2, no difference in the survival profile of HEK293T cells was observed in either the presence or absence of GH. In contrast, CHO-4 cells showed increased survival when they had been exposed to GH prior to irradiation (Fig. 2). This effect was dose dependent, indicating that it was mediated by the biological activity of the $\mathrm{GH}$ receptor. We have observed that higher doses $(400 \mathrm{nmol} / \mathrm{l})$ were toxic for cells (data not shown); consequently the dose range used was $50-200 \mathrm{nmol} / \mathrm{l}$. We have also studied the effect of $\mathrm{GH}$ when cells were treated with the radiomimetic drug, bleomycin, and another drug, vincristin, which does not affect DNA in any way (Fig. 3). Our results showed that $\mathrm{GH}$ was also able to protect CHO-4 cells from bleomycin-induced cell death. In contrast, when cells were treated with the microtubule interfering agent vincristin, GH was not able to protect cells from the cytotoxic activity of the drug. These findings suggest that the protection induced by GH can be specific against agents that provoke DNA double-strand breaks.

\section{Treatment of cells with GH facilitates repair of transfected DNA}

Although the protective effect observed in cells treated with GH could be due to interference by the hormone in the response of the cells to irradiation at different levels, the above results strongly support the hypothesis that GH increases the activity of the DNA repair machinery. In order to test this possibility we performed different assays measuring reactivation of gene expression after irradiation in the presence of $\mathrm{GH}$, as an indicator of DNA repair. CHO-4 cells were transfected with the plasmid pHIV-LUC, starved of serum for $16 \mathrm{~h}$, treated with GH for $4 \mathrm{~h}$ and then irradiated and collected at different times. No effect of $\mathrm{GH}$ on basal transcription of the pHIV-LUC reporter was detected (data not shown), indicating that any change in the activity could be due to repair of the damaged plasmid. As shown in Fig. 4A, a time-dependent decrease in luciferase activity was observed, after irradiation, in the absence of GH. In contrast, cells pretreated with GH maintained luciferase activity during the $24 \mathrm{~h}$ period, indicating that repair

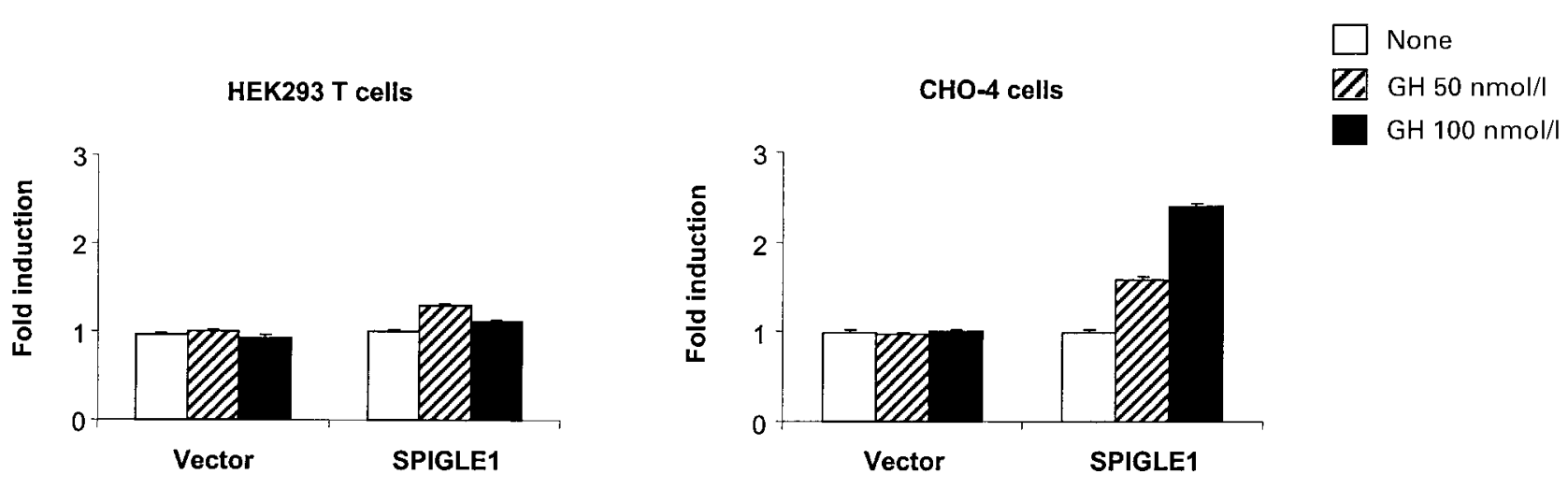

Figure 1 Induction of STAT5 dependent transcription by GH in CHO-4 cells. HEK293T and CHO-4 cells were transfected with $5 \mu \mathrm{g}$ SPIGLE1 plasmid or empty vector. After $16 \mathrm{~h}$ of growth in low serum medium, cells were stimulated with the indicated doses of GH, harvested after $6 \mathrm{~h}$ of treatment and processed for CAT activity. Data represent mean and standard deviation of a single experiment performed in triplicate. The experiment was performed three times in triplicate and the results were similar. 
HEK293T cells

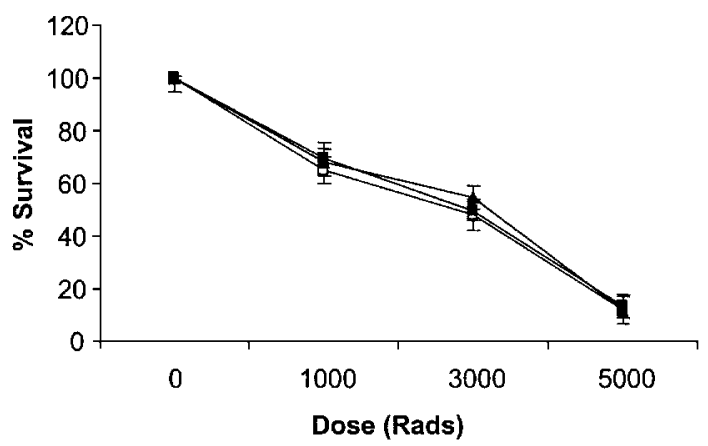

CHO-4 cells

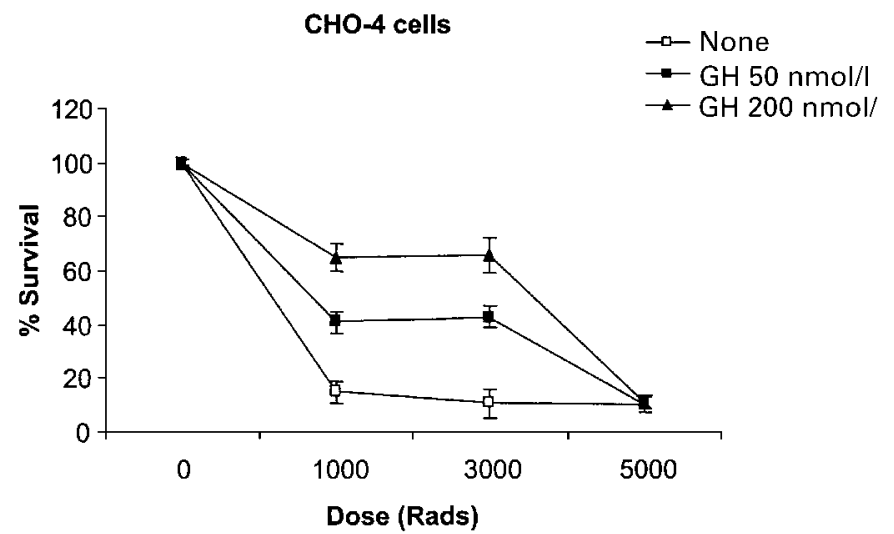

Figure $2 \mathrm{CHO}-4$ and HEK293T cell survival to radiation. HEK293T and CHO cells were seeded in $60 \mathrm{~mm}$ dishes, treated with GH at the indicated concentrations and irradiated at doses ranging between 0 and 5000 rads. After 10 days cell survival was estimated by Crystal Violet stain. Data represent means and standard deviations of a single experiment performed in triplicate. The experiments were carried out three times in triplicate and similar results were obtained.

of the transcribed strand was more active in the presence of GH. To confirm this effect of GH, additional experiments were carried out in CHO-4 cells transfected with pHIV-LUC reporter and exposed to different doses of the radiomimetic drug bleomycin in the presence or the absence of GH. As observed in Fig. 4B, bleomycin treatment produced a time- and dose-dependent decrease in luciferase activity. However, reporter activity was maintained up to $40 \mathrm{~h}$ after the addition of the drug when CHO-4 cells were pretreated with $\mathrm{GH}$. The effect of GH on the sustaining transcriptional activity in the CHO-4 cells that were irradiated or treated with bleomycin, might be the result of inhibited DNA degradation rather than increased DNA repair. To clarify this possibility we treated the pHIV-LUC reporter with two different radiation doses and then transfected the irradiated DNA together with non-irradiated pCMV- $\beta$ gal, as a control for transfection efficiency. After transfection, cells were serum depleted for $16 \mathrm{~h}$, stimulated with different doses of $\mathrm{GH}$ and collected $40 \mathrm{~h}$ after treatment. The results showed that transcription of pHIV-LUC decreased in a dose-dependent fashion when DNA was irradiated (Fig. 5). When cells were transfected with irradiated DNA (1000 rads), the recovery of transcription was similar with the two GH doses used. However, the highest GH dose was more effective than the lower doses when the radiation dose was 3000 rads. Since the results were corrected for differences in transfection efficiency, these experiments strongly suggest that the action of GH on transcription reactivation was due to repair of the damaged pHIV-LUC reporters.

\section{Discussion}

This study demonstrates that $\mathrm{GH}$ is radioprotective in CHO-4 cells that express the GH receptor and the protective action of $\mathrm{GH}$ on radiation-induced injury is dose dependent. A similar conclusion was obtained
A)

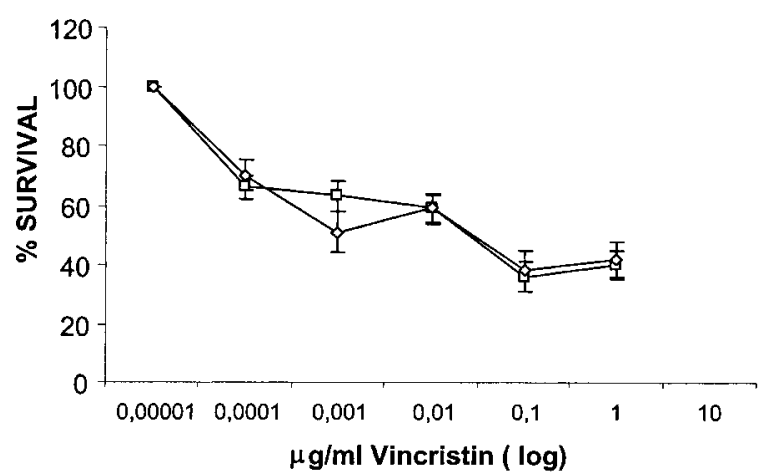

B)

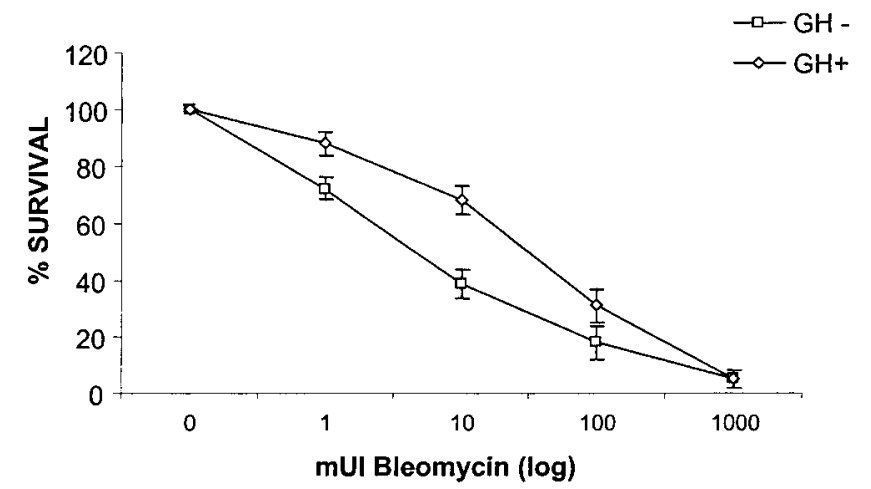

Figure $3 \mathrm{CHO}-4$ cells survival after vincristin and bleomycin treatment. $\mathrm{CHO}$ cells were seeded in 24-well dishes, and $16 \mathrm{~h}$ later were treated with vincristin or bleomycin at the indicated concentrations in the presence or absence of $\mathrm{GH}(200 \mathrm{nmol} / \mathrm{l})$. After $72 \mathrm{~h}$ cell survival was estimated by Crystal Violet stain. The data represent means and standard deviations from a single experiment performed in triplicate. The experiments were repeated twice and similar results were obtained. 
A)

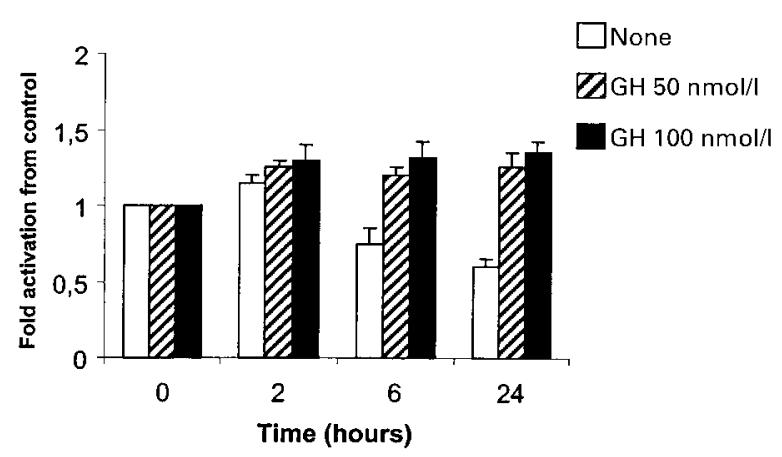

B)

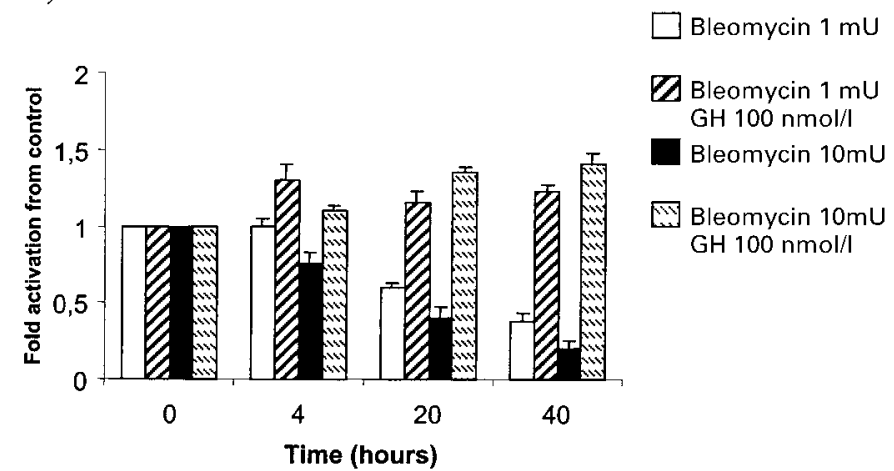

Figure 4 Reactivation of pHIV-LUC expression in CHO-4 cells after treatment with radiotherapy and bleomycin. (A) CHO-4 cells were transfected with pHIV-LUC reporter vector. After $16 \mathrm{~h}$ of low serum growth cells were treated with $\mathrm{GH}$ at the indicated doses and irradiated with 1000 rads. Cell lysates were prepared at the indicated times and assayed for luciferase activity. Data represent the means of three experiments performed in duplicate. (B) CHO-4 cells were transfected with pHIV-LUC reporter vector. After 16 h of low serum growth cells were treated with $\mathrm{GH}$ at the indicated doses and treated with the indicated doses of bleomycin. Cell lysates were prepared at the indicated times and assayed for luciferase activity. Data represent the means and standard deviations from three experiments performed in duplicate.

when the radiomimetic drug, bleomycin, was used. Bleomycin, an agent also used in cancer treatment, has to be activated to induce direct oxidative damage to DNA (32). The rescue from cell death by GH seems to be selective for agents that damage DNA, since cells treated with the microtubule disturbing agent, vincristin, did not show any difference when they were pretreated with GH. Goh et al. (33) reported that $\mathrm{GH}$ treatment reduces the apoptosis induced by colchicine in CHO-4 cells that express the $\mathrm{GH}$ receptor. These authors measured apoptosis at short time intervals after colchicine treatment. Since our experiments measured cell survival at 10 days after radiation exposure and $72 \mathrm{~h}$ after drug treatment, we believe our data measure the fraction of survival after treatment more accurately. Many actions of GH are mediated by IGF-I, and both factors share many overlapping effects in both physiological and cellular terms; IGF-I possesses antiapoptotic effects. It even up-regulates the level of bcl-xL gene product (34), a member of the antiapoptotic Bcl-2 family. In our study, the survival effect observed in GH-treated CHO4 cells was not due to induced IGF-I secretion, since CHO-4 cells neither synthesise nor secrete IGF-I either when deprived of serum or after GH stimulation $(35,31)$.

One of the mechanisms for radioprotection involves induction of biochemical and enzymatic pathways that prevent radiation-induced damage and/or promote DNA repair (36). We have found that plasmid DNA transfected in CHO-4 cells was more actively transcribed in cells treated with GH than in non-treated cells. Transcription activity also recovered more quickly in GH-treated cells exposed to bleomycin. These results suggest that GH activates pathways involved in DNA repair processes. Another explanation for our results would be that cell death inhibition, induced by GH, could protect either plasmid DNA or the protein product from degradation, and this would produce a more active transcription. However, reporter plasmid transcription was also more active in cells transfected with radiation-damaged DNA when

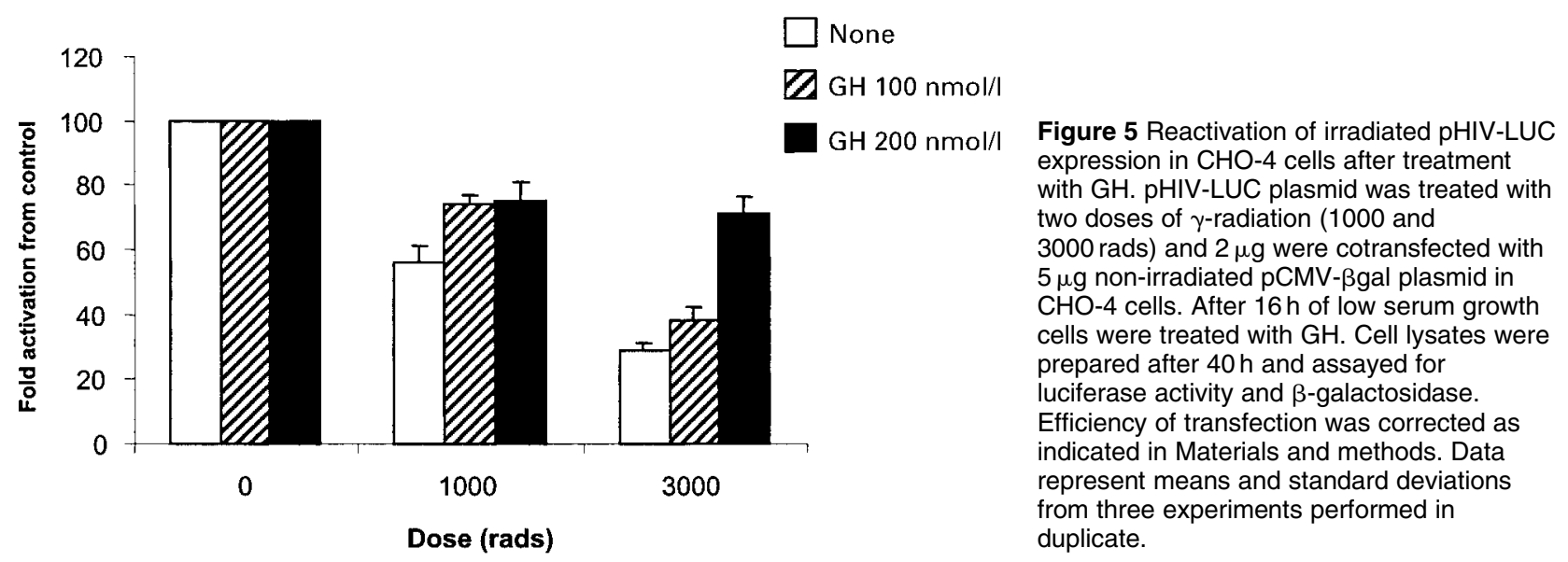


they were pre-treated with GH. Since the cells themselves were not exposed to radiation, the observed effects cannot be a consequence of apoptotic protection and suggest that DNA repair has been activated. This finding is also consistent with a recent study in rat liver (37) showing that GH induces the expression of several genes implicated in the control of DNA damage and in the response of cells to stress. Namely, GADD45, which inhibits mitotic growth (38), and APEN, which is both a DNA repair enzyme (39) and an activator of several transcription factors (40). Thus, GH may have a role in defending against cell stress and DNA damage. In this line, the results shown here may also explain an effect reported by our group in rats which were exposed to abdominal $\gamma$-radiation and whose survival was increased by $50 \%$ if the animals had been treated with human GH (24). The increase in survival was associated with reduced bacterial translocation, speedier increases in mucosal thickness and proliferative index and a decrease in apoptosis, suggesting that giving GH to irradiated rats promoted the adaptive process of the intestine against acute radiation-related negative effects.

Interaction of $\mathrm{GH}$ with its receptor induces the activation of signalling cascades including the JAK2 tyrosine kinase (41), MAPK $(42,31)$, activation of insulin receptor substrate (IRS)-1 and IRS-2 (43, 44), Phosphatidylinositol 3-kinase (45), Src homologous and collagen-like protein, Grb2 (46), Protein kinase C and phospholipase A2 (16) among others. Some of these pathways, particularly those driven by JAK2 and MAPK, can activate transcription mediated by STAT3 and STAT5 as well as SRF and c-fos $(47,30$, 48 ) and probably activate expression of genes like GADD45 and APEN, which are involved in radiationinduced DNA repair. Alternatively, other signal transduction pathways activated by $\mathrm{GH}$ could be at the translation level and would activate the assemblage of DNA repair complexes. These possibilities are the subjects of ongoing research by our group.

\section{Acknowledgements}

We thank Ignacio Carralero for providing GH, Juan Carlos Lacal for providing the SPIGLE1 plasmid, Antonio Garcia-Grande and Ana Escribano for performing the radiotherapy protocols. IS-P is a P.D. fellow from Comunidad Autónoma de Madrid. This study was supported by grants from Fondo de Investigación Sanitaria 98/0514, 00/0263 and 00/0862 and Comunidad Autónoma de Madrid 08.1/0035/1998, 08.1/0007.1/99.

\section{References}

1 Ward JF. DNA damage produced by ionizing radiation in mammalian cells: identities, mechanisms of formation, and reparability. Progress in Nucleic Acid Research and Molecular Biology $19883595-125$.

2 McMillan TJ. Residual DNA damage: what is left over and how does this determine cell fate? European Journal of Cancer 1992 28 267-269.

3 Fuks Z, Persaud RS, Alfieri A, McLoughlin M, Ehleiter D, Schwartz JL et al. Basic fibroblast growth factor protects endothelial cells against radiation-induced programmed cell death in vitro and in vivo. Cancer Research $1994 \mathbf{5 4} 2582-2590$.

4 Paris F, Fuks Z, Kang A, Capodieci P, Juan G, Ehleiter D et al. Endothelial apoptosis as the primary lesion initiating intestinal radiation damage in mice. Science 2001293 293-297.

5 Howarth GS, Fraser R, Frisby CL, Schirmer MB \& Yeoh EK. Effects of insulin-like growth factor-I administration on radiation enteritis in rats. Scandinavian Journal of Gastroenterology 1997 32 1118-1124.

6 Farrell CL, Bready JV, Rex KL, Chen JN, DiPalma CR, Whitcomb $\mathrm{KL}$ et al. Keratinocyte growth factor protects mice from chemotherapy and radiation-induced gastrointestinal injury and mortality. Cancer Research 199858 933-939.

7 Okunieff P, Mester M, Wang J, Maddox T, Gong X, Tang D et al. In vivo radioprotective effects of angiogenic growth factors on the small bowel of C3H mice. Radiation Research $1998150204-211$.

8 Houchen CW, George RJ, Sturmoski MA \& Cohn SM. FGF-2 enhances intestinal stem cell survival and its expression is induced after radiation injury. American Journal of Physiology 1999276 G249-G258.

9 Neta R, Stiefel SM, Finkelman F, Herrmann S \& Ali N. IL-12 protects bone marrow from and sensitizes intestinal tract to ionizing radiation. Journal of Immunology 1994153 4230-4237.

10 Neta R, Oppenheim JJ \& Douches SD. Interdependence of the radioprotective effects of human recombinant interleukin 1 alpha, tumor necrosis factor alpha, granulocyte colonystimulating factor, and murine recombinant granulocytemacrophage colony-stimulating factor. Journal of Immunology $1988140108-111$.

11 Redlich CA, Gao X, Rockwell S, Kelley M \& Elias JA. IL-11 enhances survival and decreases TNF production after radiation-induced thoracic injury. Journal of Immunology 1996 157 1705-1710.

12 Potten CS. Protection of the small intestinal clonogenic stem cells from radiation-induced damage by pretreatment with interleukin 11 also increases murine survival time. Stem Cells 199614 452-459.

13 Wu SG \& Miyamoto T. Radioprotection of the intestinal crypts of mice by recombinant human interleukin-1 alpha. Radiation Research $1990123112-115$.

14 Potten CS, Booth D \& Haley JD. Pretreatment with transforming growth factor beta-3 protects small intestinal stem cells against radiation damage in vivo. British Journal of Cancer $1997 \mathbf{7 5}$ $1454-1459$.

15 Fiebig HH, Dengler W \& Hendriks HR. No evidence of tumor growth stimulation in human tumors in vitro following treatment with recombinant human growth hormone. Anticancer Drugs $200011659-664$.

16 Argetsinger LS \& Carter Su C. Mechanism of signaling by growth hormone receptor. Physiological Reviews 199676 1089-1107.

17 Cheek DB \& Hill DE. Effect of growth hormone on cell and somatic growth. In Handbook of Physiology, ch. 4, pp 159-185. Eds E Knobil \& W Sawyer. Washington DC: American Physiological Society, 1974.

18 Neely EK \& Rosenfeld RG. Use and abuse of human growth hormone. Annual Review of Medicine 199445 407-420.

19 Jiang ZM, He GZ, Zhang SY, Wang XR, Yang NF, Zhu Y et al. Low-dose growth hormone and hypocaloric nutrition attenuate the protein-catabolic response after major operation. Annals of Surgery $1989210513-524$.

20 Slonim AE, Bulone L, Damore MB, Goldberg T, Wingertzahn MA \& McKinley MJ. A preliminary study of growth hormone therapy for Crohn's disease. New England Journal of Medicine $2000 \mathbf{3 4 2}$ $1633-1637$. 
21 Chen K, Nezu R, Inoue M, Wasa M, Iiboshi Y, Fukuzawa M et al. Beneficial effects of growth hormone combined with parenteral nutrition in the management of inflammatory bowel disease: an experimental study. Surgery 1997121 212-218.

22 Byrne TA, Morrissey TB, Gatzen C, Benfell K, Nattakom TV, Scheltinga MR et al. Anabolic therapy with growth hormone accelerates protein gain in surgical patients requiring nutritional rehabilitation. Annals of Surgery 1993218 400-416.

23 Raff T \& Germann G. Growth hormone in surgery-an assessment of current knowledge. Der Chirurg 199768 995-1003.

24 Gomez de Segura IA, Prieto I, Grande AG, Garcia A, Mendez J et al. Growth hormone reduces mortality and bacterial translocation in irradiated rats. Acta Oncologica 199837 179-185.

25 Perona R, Montaner S, Saniger L, Sanchez Perez I, Bravo R \& Lacal JC. Activation of the nuclear factor-kappaB by Rho, CDC42, and Rac-1 proteins. Genes and Development 199711 463-475.

26 Wood TJ, Sliva D, Lobie PE, Goullieux F, Mui AL, Groner B et al. Specificity of transcription enhancement via the STAT responsive element in the serine protease inhibitor 2.1 promoter. Molecular and Cellular Endocrinology 1997130 69-81.

27 Sanchez Perez I, Murguia JR \& Perona R. Cisplatin induces a persistent activation of JNK that is related to cell death. Oncogene $199816533-540$.

28 Francis SM, Enerback S, Moller C, Enberg B \& Norstedt G. A novel in vitro model for studying signal transduction and gene regulation via the growth hormone receptor. Molecular Endocrinology $19937972-978$.

29 Fiddes RJ, Brandon MR \& Adams TE. Functional expression of an ovine growth hormone receptor in transfected Chinese hamster ovary cells. Molecular and Cellular Endocrinology 1992 $8637-47$.

30 Pircher TJ, Flores Morales A, Mui AL, Saltiel AR, Norstedt G, Gustafsson JA et al. Mitogen-activated protein kinase kinase inhibition decreases growth hormone stimulated transcription mediated by STAT5. Molecular and Cellular Endocrinology 1997 $133169-176$.

31 Moller C, Hansson A, Enberg B, Lobie PE \& Norstedt G. Growth hormone $(\mathrm{GH})$ induction of tyrosine phosphorylation and activation of mitogen-activated protein kinases in cells transfected with rat GH receptor cDNA. Journal of Biological Chemistry 1992 267 23403-23408.

32 Povirk LF \& Austin MJ. Genotoxicity of bleomycin. Mutation Research 1991257 127-143.

33 Goh EL, Pircher TJ \& Lobie PE. Growth hormone promotion of tubulin polymerization stabilizes the microtubule network and protects against colchicine-induced apoptosis. Endocrinology $19981394364-4372$.

34 Parrizas M, Saltiel AR \& LeRoith D. Insulin-like growth factor 1 inhibits apoptosis using the phosphatidylinositol $3^{\prime}$-kinase and mitogen-activated protein kinase pathways. Journal of Biological Chemistry 1997272 154-161.

35 Goh EL, Pircher TJ, Wood TJ, Norstedt G, Graichen R \& Lobie PE. Growth hormone-induced reorganization of the actin cytoskeleton is not required for STAT5 (signal transducer and activator of transcription-5)-mediated transcription. Endocrinology $19971383207-3215$

36 Dittmann KH, Gueven N, Mayer C \& Rodemann HP. The radioprotective effect of $\mathrm{BBI}$ is associated with the activation of DNA repair-relevant genes. International Journal of Radiation Biology $199874225-230$.

37 Thompson BJ, Shang CA \& Waters MJ. Identification of genes induced by growth hormone in rat liver using cDNA arrays. Endocrinology $20001414321-4324$.

38 Zhan Q, Lord KA, Alamo I, Hollander MC, Carrier F, Ron D et al. The gadd and $M y D$ genes define a novel set of mammalian genes encoding acidic proteins that synergistically suppress cell growth. Molecular and Cellular Biology $1994142361-2371$.

39 Rothwell DG, Barzilay G, Gorman M, Morera S, Freemont P \& Hickson ID. The structure and functions of the HAP1/Ref-1 protein. Oncology Research 19979 275-280.

40 Jayaraman L, Murthy KG, Zhu C, Curran T, Xanthoudakis S \& Prives C. Identification of redox/repair protein Ref-1 as a potent activator of p53. Genes and Development 199711 558-570.

41 Argetsinger LS \& Carter Su C. Growth hormone signalling mechanisms: involvement of the tyrosine kinase JAK2. Hormone Research 199645 (Suppl 1) 22-24.

42 Love DW, Whatmore AJ, Clayton PE \& Silva CM. Growth hormone stimulation of the mitogen-activated protein kinase pathway is cell type specific. Endocrinology 1998139 1965-1971.

43 Argetsinger LS, Hsu GW, Myers MG, Billestrup N, White MF \& Carter Su C. Growth hormone, interferon-gamma, and leukemia inhibitory factor promoted tyrosyl phosphorylation of insulin receptor substrate-1. Journal of Biological Chemistry $1995 \mathbf{2 7 0}$ 14685-14692.

44 Argetsinger LS, Norstedt G, Billestrup N, White MF \& Carter $\mathrm{Su}$ C. Growth hormone, interferon-gamma, and leukemia inhibitory factor utilize insulin receptor substrate-2 in intracellular signaling. Journal of Biological Chemistry $1996 \mathbf{2 7 1}$ 29415-29421.

45 Jeay S, Sonenshein GE, Kelly PA, Postel Vinay MC \& Baixeras E. Growth hormone exerts antiapoptotic and proliferative effects through two different pathways involving nuclear factor-kappaB and phosphatidylinositol 3-kinase. Endocrinology $2001 \quad 142$ 147-156.

46 VanderKuur J, Allevato G, Billestrup N, Norstedt G \& Carter Su C. Growth hormone-promoted tyrosyl phosphorylation of SHC proteins and SHC association with Grb2. Journal of Biological Chemistry $1995 \mathbf{2 7 0} 7587-7593$.

47 Wang YD \& Wood WI. Amino acids of the human growth hormone receptor that are required for proliferation and Jak-STAT signaling. Molecular Endocrinology $19959303-311$.

48 Ihle JN, Witthuhn BA, Quelle FW, Yamamoto K \& Silvennoinen O. Signaling through the hematopoietic cytokine receptors. Annual Review of Immunology 199513 369-398.

Received 7 November 2001

Accepted 3 June 2002 